\title{
Common genetic hair shaft abnormalities may be visualized by light and electron microscope
}

\author{
Saad R Abed* \\ MSc. of Pharmacology, MBChB, GP of DVD. Thiqar/ Alhussain Teaching Hospital, Iraq
}

\begin{abstract}
Background: Abnormalities in keratin gene clusters either acidic cluster or basic cluster leads to hair shaft abnormalities. Hair shaft abnormalities can be divided into those with increased hair fragility or not associated with hair fragility

Objective: Light and electron microscopic studies of hair shaft abnormalities performed to better define, the microscopic changes seen in Hair shaft.

Methods: Biopsy specimens were obtained from 13 patients, 11 children and 2 adults. The hair follicles were studied by light and electron microscopy.

Results: The results show that characteristic light microscopy features of Netherton syndrome, monilethrix, woolly hair syndrome, pilitorti, piliannulati and trichothiodystrophy and others may be visualized by light and electron microscopy.
\end{abstract}

\section{Introduction}

Hair shaft abnormalities encompass a group of congenital or acquired alterations which involve the hair shaft. Single gene disorders are characterized by hair abnormalities. Hair changes may be a significant fin- ding or even the initial presentation of a syndrome giving the clue to the diagnosis, in diseases such as trichothiodystrophy or Netherton syndrome [1-3]. They usually lack macroscopic features, which would enable easy diagnosis in medical practice. Thus, the usual diagnostic method is light microscopy and every time about 40 - 50 hairs are plucked to decrease the risk of missing a hair with the characteristic abnormality under light microscope [4]. The aim of this study was to verify whether hair shaft abnormalities may be visualized by light and electron microscope of common genetic hair shaft abnormalities.

Methods: A total of 13 of different hair shaft abnormalities these are (Netherton Syndrome and Monilethrix, Woolly hair syndrome (WHS), Trichothiodystrophy, Acquired progressive kinking of the hair) In all patients, light microscopy evaluation When applicable, polarized light microscopy, scanning electron microscopy were perform considerably higher in the temporal and occipital area (90\%), as compared to the vertex and parietal area of the scalp (40\%).

Results: The results show that characteristic light microscopy features of Netherton syndrome, monilethrix, woolly hair syndrome, pili torti, pili annulati and trichothiodystrophy and others may be visualized by light and electron microscope. These genetic hair shaft abnormalities are

\section{Netherton syndrome}

Trichorrhexis invaginata and golf tee-like end were visualized by electron microscope. also known as bamboo hair [5].

- Commonly seen in association with ichthyosiss linearis circumflexa in patients with Netherton syndrome. from pathogenic mutations in the SPINK5 gene.
- Atopy is commonly seen in affected individuals.

- The breakage points consist of intussusceptions of the distal shaft ("ball") into the proximal shaft ("socket") due to defective cornification of the cortex. In adults, the scalp hair tends to improve but bamboo defects in the eyebrow and body hair may persist.

\section{Monilethrix}

Monilethrix is a term of Greek and Latin derivation meaning "necklace [6]

- hair". This disorder is inherited in an autosomal dominant fashion.

- Normal appearing hair at birth,

- Later on, replaced by short fragile brittle hair.

- perifollicular erythema \& follicular hyperkeratosis.

- Hair has uniform elliptical nodes of normal thickness and intermittent abnormal constrictions. Monilethrix. Hypotrichosis due to breakage of fragile hairs. Note the small perifollicular papules with scale.

Mutation have been found in the genes that encode K83 and in patients with autosomal recessive form Desmoglein.

Usually, the scalp is the only region involved, but in more extensive cases there may be eyebrow, eyelash and nail involvement.

${ }^{\star}$ Correspondence to: Saad R Abed, MSc. of Pharmacology, MBChB, GP of DVD. Iraq/ Thiqar/ Alhussain Teaching Hospital, Iraq, E-mail: alnasiry_saad68@ yahoo.com

Key words: hair shaft, trichothiodystrophy

Received: December 06, 2018; Accepted: December 14, 2018; Published: December 20, 2018 


\section{Woolly hair syndrome (WHS)}

Light microscopy revealed ovoid cross sections, 180-degree longitudinal twisting, trichorrhexis nodosa and pili annulate $[7,8]$. By scanning microscopy examination, the hairs were flat, appearing as oval or irregular on transverse sections with longitudinal and transverse grooves. In the distal end of the cuticle, cells were either damaged or absent, and the cortex and medulla were vacuolated.

\section{Pili torti}

- Pili tortiis characterized by a flattened shaft and twisting of the hair fiber on its own axis [9].

- Classic pili torti is part of a clinical syndrome.

- with ectodermal abnormalities (keratosis pilaris, nail dystrophies, dental abnormalities.

- Björnstad syndrome associated with sensorineural hearing loss. Acquired pili torti-like hair shaft twisting has been reported in association with anorexia nervosa and oral retinoid therapy.

- Menkes disease is an X-linked recessive disorder of copper metabolism.

\section{Trichothiodystrophy}

- an autosomal recessive disorder characterized by sulfur-deficient hair [10].

- marker for a neuroectodermal symptom complex.

- alternating light and dark bands by polarizing microscopy.

- PIBIDS refers to a phenotype consisting of: P (photosensitivity), I (ichthyosis), B (brittle hair), I (intellectual impairment with low IQ), D (decreased fertility) and S (short stature).

- Acquired progressive kinking of the hair

\section{Acquired curling of the scalp hair}

- young men develop curly, frizzy and lusterless hair in the frontotemporal region or vertex of the scalp [11].

- Localized and diffuse forms.

- subsequent progression to androgenetic alopecia.

\section{Loose anagen hair syndrome}

- The classic presentation is a young girl with fairly short blond hair that seldom needs cutting [12].

- Anagen hair can be easily and painlessly pulled from the scalp microscopic examination reveals a ruffled proximal cuticle, absence of the root sheath, and a bent matrix

- result from faulty cornification of the inner root sheath. This would then interfere with normal interdigitation of the inner root sheath cuticle with the hair cuticle, leading to poor anchoring.

\section{Pili bifurcati}

- This hair fiber anomaly is characterized by bifurcation of the hair fiber at multiple irregular intervals along the shaft [13].

- forming separate rami, which then again fuse.

- Each ramus has its own cuticle.

\section{Pili multigemini}

The term pili multigemini is associated with multiple hair shafts arising from one papilla [14].

- Each hair fiber has its own inner root sheath. But all the fibers are surrounded by a common outer root sheath.

- Multigeminate hairs are usually found in the beard region.

\section{Spun-glass hair (uncombable hair)}

- This entity is also known as pili trianguli et canaliculi [15].

- Hair is characteristically stiff and difficult to comb.

- Abnormal keratinization of the internal root sheath is postulated to cause the irregularly shaped hair shafts. Which have a triangular shape on cross-section and a longitudinal groove that is best seen by scanning electron microscopy.

\section{Discussion}

The results of this study show that characteristic light microscopy features of most genetic hair shaft abnormalities may be visualized by light microscope and electronic microscope.

The Netherton syndrome is characterized by three major clinical features: ichthyosiform dermatosis (non-bullous ichthyosiform erythroderma or as ichthyosis linearis circumflexa), atopy and a characteristic hair abnormality. Clinically hair appears sparse, dull, brittle and short. The hair shaft abnormality, called bamboo hair or trichorhexisinvaginata is microscopically characterized by an invagination of the distal portion of the hair shaft into its proximal portion forming a "ball in cup" appearance and is considered pathognomonic for Netherton syndrome. Occasionally ragged, cupped proximal hair end may be seen, where the fragile node has fractured. This abnormality is often referred to as "golf-tee hairs" $[16,17]$. The diagnosis of Netherton syndrome can be difficult. Often, there is no family history and concomitant atopy may lead to misdiagnosis of atopic dermatitis or severe eczema. Differential diagnosis has to include Omenn's syndrome, generalized seborrhoeic dermatitis, erythrodermic psoriasis, staphylococcal scaled skin syndrome, nonbullous ichtiosiform erythroderma and atopic dermatitis [18]. The basis for diagnosis is microscopically confirmed trichorrhexis invaginata. Although a single hair with characteristic invagination is sufficient to establish the diagnosis of Netherton syndrome [19].

Monilethrix is an autosomal dominant hair disorder characterized by periodic thinning of hair shafts and a tendency to fracture at constricted points. This abnormality results clinically in hair fragility and patchy dystrophic alopecia [20]. The hairs are seldom longer than 5 to 8 centimeters. The effect of disease on hair is variable and may range even within families from close to normal or mild occipital hair loss to near total alopecia. Other hairy areas, such as the eyebrows, eyelashes, axillary hair, pubic hair and body hair may also be involved. Follicular abnormalities seen in monilethrix range from subtle perifollicular erythema and hyperkeratosis to horny follicular papule formation [21]. Mutations in hair specific keratins, especially hHb1 and hHb6, which are primarily expressed in cortical trichocytes, cause predominantly structure abnormalities of hair cortex. These are in particular multiple constrictions of hair shaft, which alternate with elliptical nodosities [22]. Despite characteristic microscopic findings, the disease is not simple to diagnose in dermatological practice, especially in mild cases of the disease. Recently, a case of a patient with monilethtix has been described, in which the diagnosis was first established at the age of 44 . 
Electroscopic imaging of the scalp and hair in monilethrix demonstrated an unusual picture of hair shafts with beaded appearance, bended regularly at multiple lo- cations with tendency to curve in different directions, giving it an appearance of a regularly bended ribbon.

The existence of pseudo monilethrix is an issue of controversy. According to some authors pseudo monilethrix is a hereditary hair weakness, in which hair shaft exhibit irregular artifactual thickenings or flattening [23]. Other authors suggest that true pseudo monilethrix does not exist and that sporadic occurrence of irregular hair shaft thickenings is an artifact produced by either procedure of pre- paring hairs for microscopic examination [24] or by excessive use of cosmetic hair care products.

Pili annulati is a rare hair shaft disorder characterized by discrete banding of hairs. The etiopathogenesis of this disorder remains unknown but it is likely to be a single gene defect [25]. It is often an incidental finding with alternating light and dark bands causing a slightly spangled appearance of the hair. The phenotype is variable, with not every hair affected, and with variability along a single hair shaft [26]. There is no association with hair fragility, however Gunter et al observed that with onset of hair thinning due to androgenic alopecia, progressive reduction of hair shaft diameter may cause increased fragility in pili annulate [27]. Light microscopy of pili annulati shows a random pattern of intermittent abnormal cavities. Light bands observed by clinical examination appear as dark bands when imaged by light microscopy. The spangled appearance is due to cortical spacer containing air in the light bands and fluid in the dark bands.

Pili torti is a rare hair shaft dysplasia due to a structural defect in which the hair shafts are flattened or ridged and twisted in their own axis, resulting in the clinical appearance of "corkscrew hairs" and in spontaneous breakage. Pili torti may be associated with many syndromes (Menkes, Bazex or Crandall syndrome) or may occur as an inherited, isolated phenomenon with the onset at birth or in the early months of life [28]. Acquired pili torti have been re- ported after treatment with oral retinoids.

In woolly hair syndrome the term "woolly hair" refers to an abnormal variant of fine, tightly curled hair that often exhibits decreased pigmentation. In 1974, Hutchinson et al. [29] classified woolly hair into 3 variants: woolly hair nevus, autosomal dominant hereditary woolly hair and autosomal recessive familial woolly hair. Since then, woolly hair has also been observed in association with several genetic conditions, especially the Noonan syndrome, which is characterized by short stature, typical facial dysmorphology and heart defects [30] and in the phenotypically overlapping cardiofaciocutaneous syndrome, which is characterized by congenital heart defect, developmental delay, peculiar facial appearance with bitemporal construction, prominent forehead, down slanting palpebral fissures, abnormalities of the skin and curly sparse hair [31]. Distinguishing woolly hair from curly hair may require evaluation of hair shafts by either light or electron microscopy [32]. Light microscopy revealed ovoid cross sections, 180-degree longitudinal twisting, trichorrhexis nodosa and pili annulati. Scanning electron microscopy revealed hairs which were flat, appearing as oval or irregular on transverse sections with longitudinal and transverse grooves. In the distal end of the cuticle cells were either damaged or absent and the cortex and medulla were vacuolated.

From all evaluated hair shaft diseases, only in the case of trichotiodystrophy is trichoscopy insufficient for making the diagnosis.

\section{Conclusion}

In conclusion, our study shows that in all hair shaft abnormalities with the exception of trichotiodystrophy.

Trichothiodystrophy, or sulfur-deficient brittle hair, identifies a group of rare and complex neuroectodermal disorders with remarkable clinical heterogeneity [33].

Clinical symptoms of trichothiodystrophy vary widely in nature and severity, and the single common feature in all patients is fragile hair. Scalp hairs, eyebrows and eyelashes are brittle, unruly, of variable lengths. With polarizing microscopy, using crossed polarizers, hair shafts show a distinctive hair feature: striking alternating bright and dark bands, often referred to as "tiger tail" banding.

Light microscopy showed hair shafts with an irregular, undulating contour and clean transverse fractures through the hair shaft (trichoschisis). The basis of this undulation is not understood, although it may reflect a weak and unstable internal cortical structure, a consequence of the major reduction in disulfide crosslinking, reflected by the low total sulfur content. Cross-sectional examination of the cuticle in hair shows lack of the exocuticle and A layer [34].

The bright and dark bands seen with polarized light correspond to the undulating orientation of the cortical fibers in Trichotiodystrophy. Hair shafts are notably flattened and may fold over like ribbon during the hair mounting process [33].

In general, it has to be pointed out that for investigating a possible hair shaft abnormality ex vivo, an appropriate sample of hairs must be collected. Hairs must be in sufficient amount to provide a reasonable chance of finding relevant positive clues. A sample of 40-50 hairs is usually adequate to allow detection of most significant abnormalities. There are exceptions, and Netherton's syndrome is one, where repeated samples of several hundred hairs may be needed to confirm the diagnosis.

\section{References}

1. Silengo M, Valenzise M, Sorasio L, Ferrero GB (2002) Hair as a diagnostic tool in dysmorphology. Clin Genet 62: 270-272. [Crossref]

2. Furdon SA, Clark DA (2003) Scalp hair characteristics in the newborn infant. $A d v$ Neonatal Care 3: 286-296. [Crossref]

3. Itin PH, Fistarol SK (2005) Hair shaft abnormalities--clues to diagnosis and treatment. Dermatology 211: 63-71. [Crossref]

4. Greene SL, Muller SA (1985) Netherton's syndrome. Report of a case and review of the literature. J Am Acad Dermatol 13: 329-337. [Crossref]

5. Muramatsu S, Kimura T, Ueki R, Tsuboi R, Ikeda S, et al. (2003) Recurrent E413K mutation of hHb6 in a Japanese family with monilethrix. Dermatology 206: 338-340. [Crossref]

6. Rudnicka L, Rakowska A, Kerzeja M, Olszewska M (2013) Hair shafts in trichoscopy: clues for diagnosis of hair and scalp diseases. Dermatol Clin 31: 695-708. [Crossref]

7. Pili annulati (2001) ringed hairs Rx microanalysis study. Actas Dermatosifiliogr 92 $147-150$

8. Mirmirani P, Samimi SS, Mostow E (2009) Pili torti: clinical findings, associated disorders and new insights into mechanisms of hair twisting. Cutis 84: 143-147.

9. Dollfus H, Porto F, Caussade P, Speeg-Schatz C, Sahel J, et al. (2003) Ocular manifestations in the inherited DNA repair disorders. Surv Ophthalmol 48: 107-122. [Crossref]

10. Bodenhorn H and Ruebeck C (2007) Colourism and African American wealth: Evidence from the nineteenth century south. Journal of Population economics 20: 599-620.

11. Hansen LK, Brandrup F, Clemmensen O (2004) Loose anagen hair syndrome associated with colobomas and dysmorphic features. Clin Dysmorphol 13: 31-32. [Crossref] 
12. Camacho FM (1996) Pili bifurcati in a woman with ulcerative colitis. Eur J Dermatol 6: $355-356$.

13. Nair PA, Kota RS, Gandhi S, Singhal RR (2016) A Rare association of Pili Multigemini and rolled hairs in a young female. Int J Trichology 8: 29-31. [Crossref]

14. Fritz TM, Trüeb RM (2000) Uncombable hair syndrome with angel-shaped phalangoepiphyseal dysplasia. Pediatr Dermatol 17: 21-24. [Crossref]

15. Sun JD, Linden KG (2006) Netherton syndrome: a case report and review of the literature. Int J Dermatol 45: 693-697. [Crossref]

16. De Berker DA, Paige DG, Ferguson DJ, Dawber RP (1995) Golf tee hairs in Netherton disease. Pediatr Dermatol 12: 7-11. [Crossref]

17. Ong C, O'Toole EA, Ghali L, Malone M, Smith VV, et al. (2004) LEKTI demonstrable by immunohistochemistry of the skin: a potential diagnostic skin test for Netherton syndrome. Br J Dermatol 151: 1253-1257. [Crossref]

18. De Berker D (2002) Clinical relevance of hair microscopy in alopecia. Clin Exp Dermatol 27: 366-372. [Crossref]

19. Gummer CL, Dawber RP, Swift JA (1981) Monilethrix: an electron microscopic and electron histochemical study. Br J Dermatol 105: 529-541. [Crossref]

20. Brzezia S, Wcis L, Bogdanowski T, Szeremeta BG, Pierzcha E (1999) Monilethrix--rare syndrome of structural hair abnormalities. Pol Merkur Lekarski 7: 226-228. [Crossref]

21. Djabali K, Panteleyev AA, Lalin T, Garzon MC, Longley BJ, et al. (2003) Recurrent missense mutations in the hair keratin gene hHb6 in monilethrix. Clin Exp Dermatol 28: 206-210. [Crossref]

22. Camacho F, Ferrando J, Rodriguez-Pichardo A (1993) Acquired pseudomonilethrix in a family with monilethrix. Eur J Dermatol 3: 651-655.

23. Zitelli JA (1986) Pseudomonilethrix. An artifact. Arch Dermatol 122: 688-690. [Crossref]
24. Green J, Fitzpatrick E, de Berker D, Forrest SM, Sinclair RD (2004) A gene for pili annulati maps to the telomeric region of chromosome 12q. J Invest Dermatol 123 1070-1072. [Crossref]

25. Streck AP, Moncores M, Sarmento DF, Barbosa HS, Weissmuller G, et al. (2007) Study of nanomechanical properities of human hair shaft in case of pili annulati by atomic force microscopy. J Eur Acad Dermatol Venereol 21: 1109-1147.

26. Hofbauer G, Tsambaos D, Spycher MA, Trueb RM (2001) Acquired hair fragility in pili annulate casual relationship with androgenic alopecia. Dermatology 203: 60-62.

27. Richards KA, Mancini AJ (2002) Three members of a family with pili torti and sensorineural hearing loss: the Bjornstad syndrome. J Am Acad Dermatol 46: 301-303. [Crossref]

28. Bazzi H, Christiano AM (2007) Broken hearts, woolly hair, and tattered skin: when desmosomal adhesion goes awry. Curr Opin Cell Biol 19: 515-520. [Crossref]

29. Chien AJ, Valentine MC, Sybert VP (2006) Hereditary woolly hair and keratosis pilaris. $J$ Am Acad Dermatol 54: S35-39. [Crossref]

30. Itin PH, Sarasin A, Pittelkow MR (2001) Trichothiodystrophy: update on the sulfurdeficient brittle hair syndromes. J Am Acad Dermatol 44: 891-920. [Crossref]

31. Sperling LC, DiGiovanna JJ (2003) "Curly" wood and tiger tails: an explanation for light and dark banding with polarization in trichothiodystrophy. Arch Dermatol 139 1189-1192. [Crossref]

32. Forslind B, Andersson MK, Alsterborg E (1991) Hereditary hair changes revealed by analysis of single hair fibres by scanning electron microscopy. Scanning Microsc 5 : $867-875$.

33. Rakowska A, Slowinska M, Kowalska-Oledzka E, Rudnicka L (2008) Trichoscopy in genetic hair shaft abnormalities. J Dermatol Case Rep 2: 14-20. [Crossref]

34. Bazzi H, Christiano AM (2007) Broken hearts, woolly hair, and tattered skin: when desmosomal adhesion goes awry. Curr Opin Cell Biol 19: 515-520.

Copyright: (C2018 Abed SR. This is an open-access article distributed under the terms of the Creative Commons Attribution License, which permits unrestricted use, distribution, and reproduction in any medium, provided the original author and source are credited. 